ارزيابى عملكرد روشهاى زمين آمار و شبكه عصبى مصنوعى در تخمين پارامترهاى كيفى آبخوان (مطالعه موردى: دشت قروه- دهخلان)

محمد عيسىزاده "*، رزگار عربزاده و و صابره دربندى'

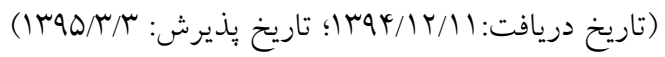

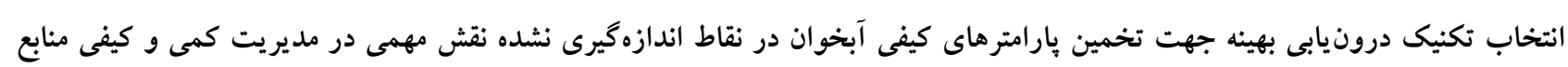

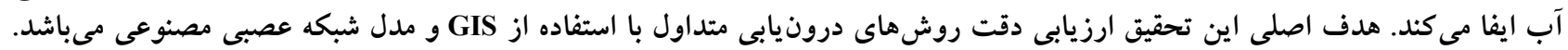

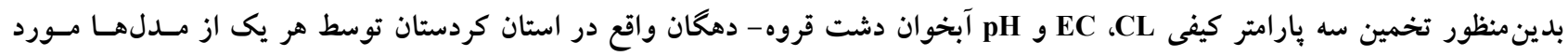

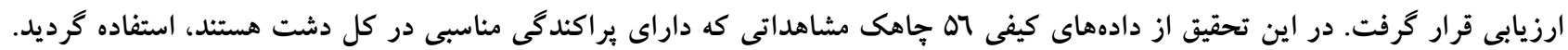

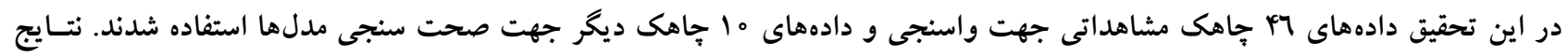

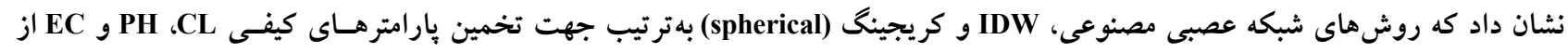

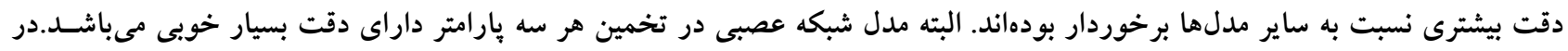

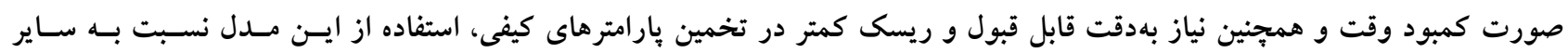
مدلهاى آمارى به كار رفته ارجحيت داردي

كلمات كليدى: تخمين بارامترهاى كيفى، شبكه عصبى مصنوعى، كريجينگ، IDW 
بدين ترتيب در اين علم مى تـوان موقعيـت فضـائى نمونسهـــا را

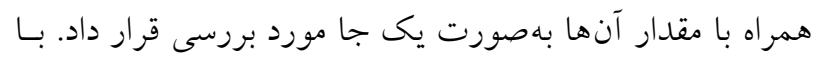

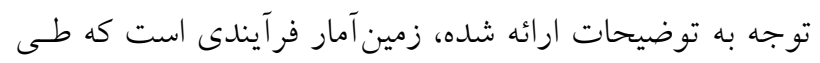

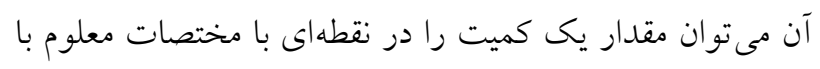

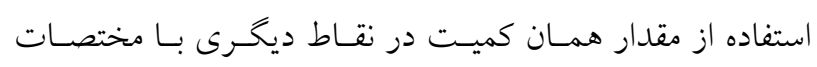

معلوم بهدست آورد (r) مان. شبكههاى عصبى مصنوعى بهعنوان يكى از روش هاى جعبـه

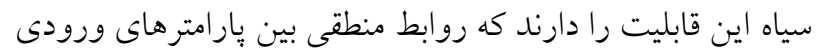
و خروجى يك بديده را بيان كنند. اين شبكهها بر مبناى مقايسـة

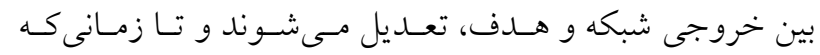
خروجى شبكه با خروجى هدف تطبيق ييدا كند، ايـن كـار ادامـه

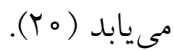
در زمينه تخمين بارامترهاى كيفى آبخــوانهـا بـا اسـتفاده از روشهاى زمين آمار و شـبكههـاى عصسبى مصـنوعى مطالعـات زيادى انجام كرفته است كه در زير به بعضى از ايسن مطالعـات

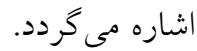
زارع ابيانه و همكاران (9) مقــادير نيتـرات را بـا استفاده از

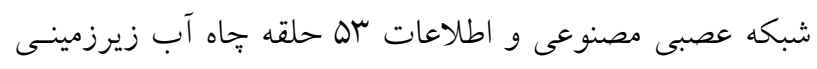

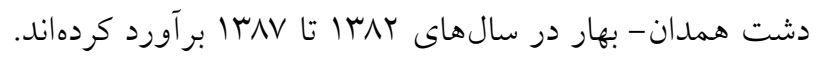

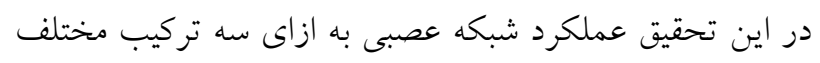
ورودى (هفت، هشـت و سـيزده ورودىى) مـورد ارزيـابى قـرار

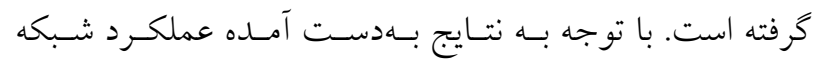

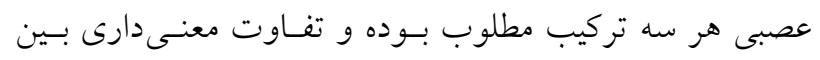

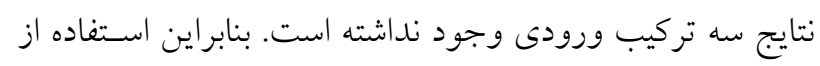
تركيب كمهزينه تر (هفت ورودى) جهت تخمين مقادير نيتـرات

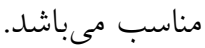

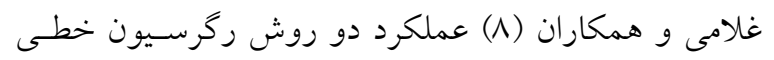
جند متغيره و شبكه عصبى مصنوعى را در مدلسازى و بــرآورد

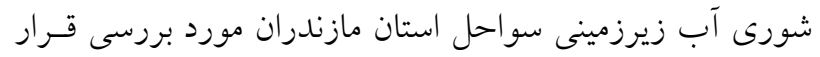
دادهاند. در اين تحقيق از هشت تركيب مختلـف ورودى شـامل هدايت الكتريكى متوسط آب سطحى، قابليـت انتقـال متوسط

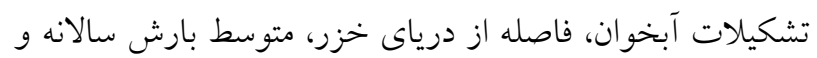

در دهلهاى اخير با ييشرفت انتـلاب صـنعتى كشـورهاى درحـال

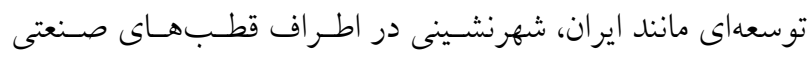

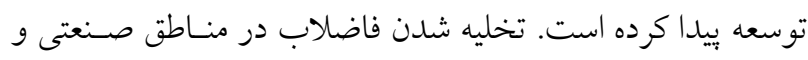

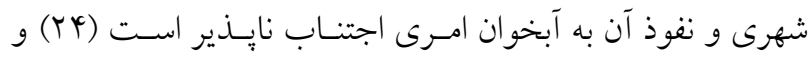

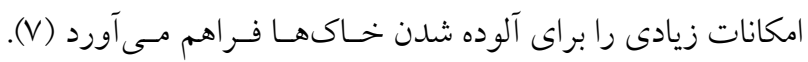

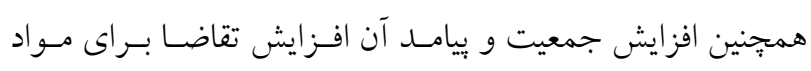

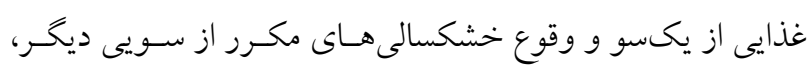

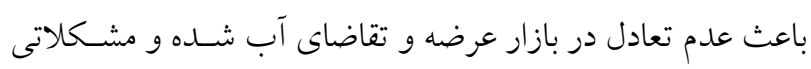

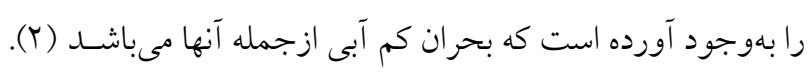

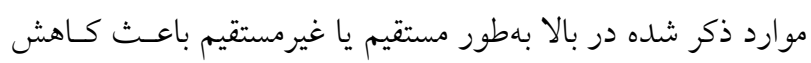

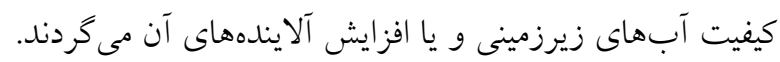

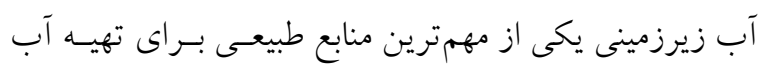

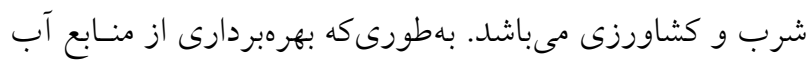

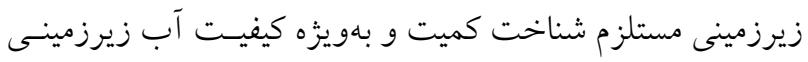

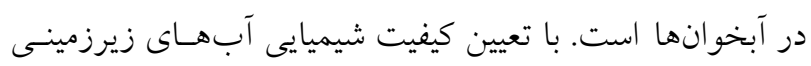

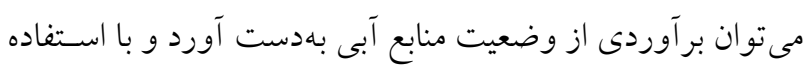

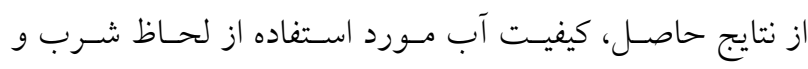

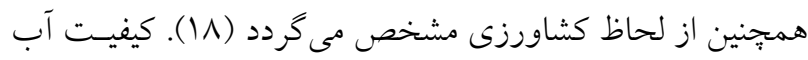

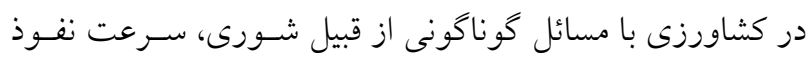

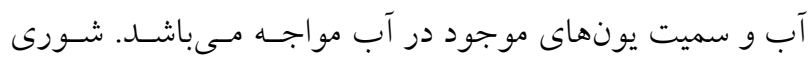

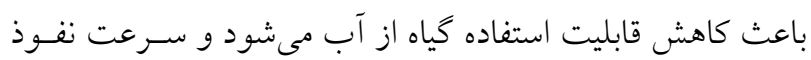

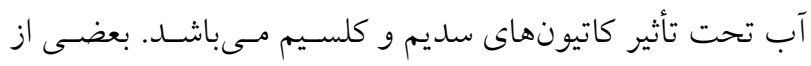

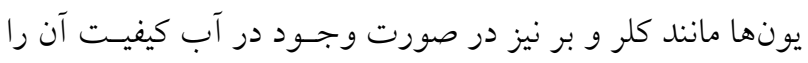

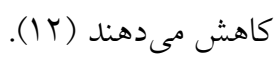

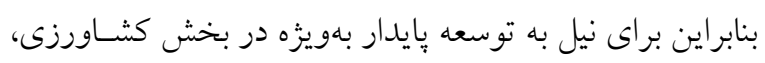

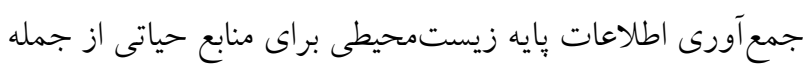

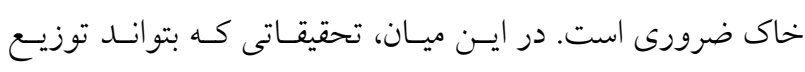

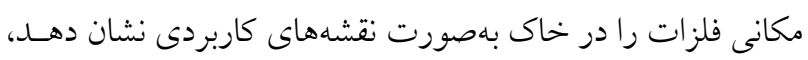

مى تو اند از جنبه مديريتى بسيار مفيد باشد (ه) (ه).

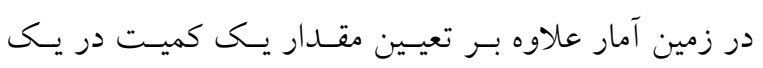

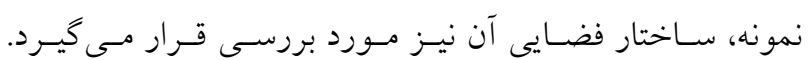


خطاى بيشبينى كرديده است.

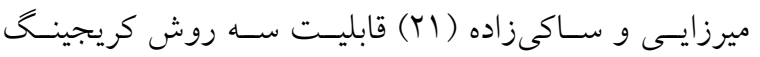

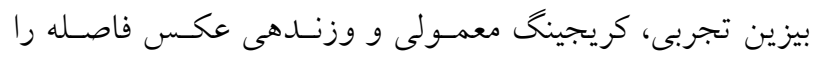

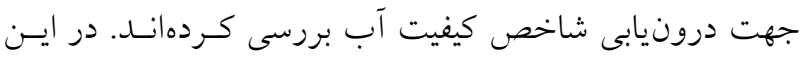

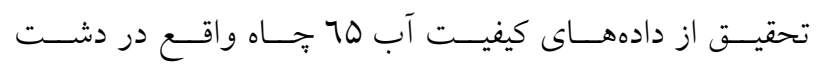

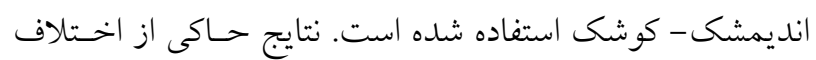

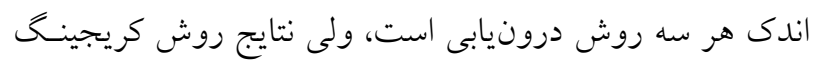
بيزين تجربى نسبت به دو روش ديخر قابل قبولتر مى بـاشد.

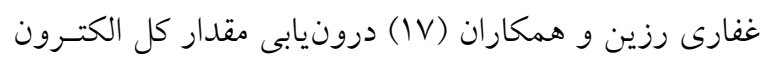

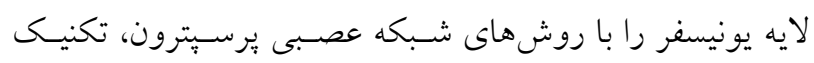

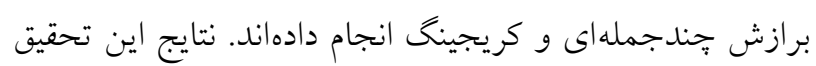

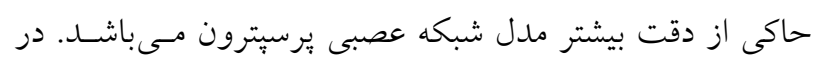

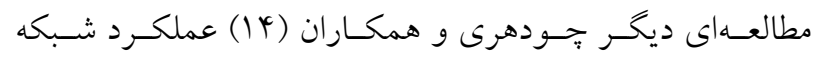
عصبى مصنوعى و كريجينگ معمولى جهـت درونيـابى مقــادير

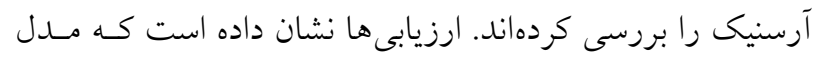

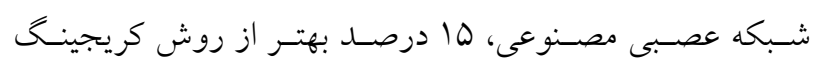
مقادير آرسنيك را تخمين زده است.

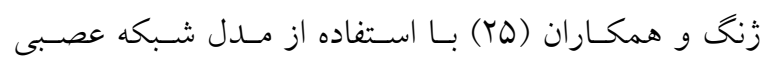

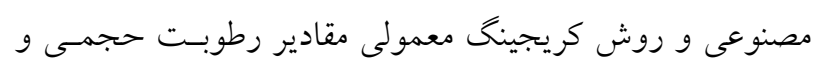

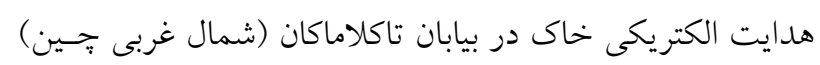

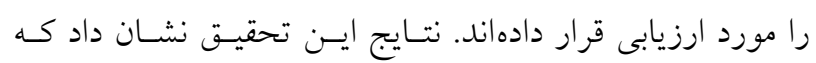

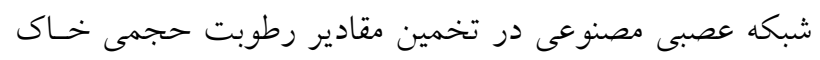
كمى بهتر و در تخمين مقادير هدايت الكتريكى خاك بسيار بهتر از مدل كريجينغ معمولى مىباشد.

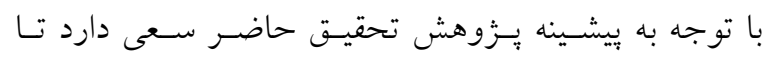

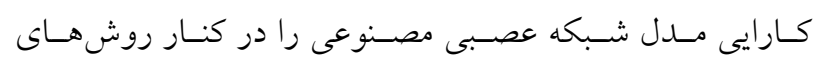

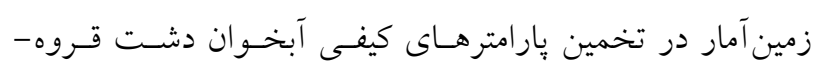

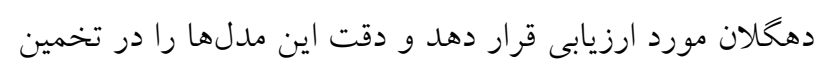
هر يك از يارامترهاى مورد نظر نسبت به يكديخر بررسى كنى كنـد.

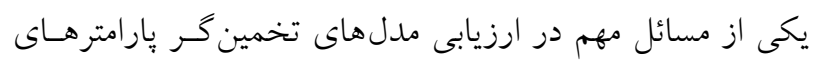

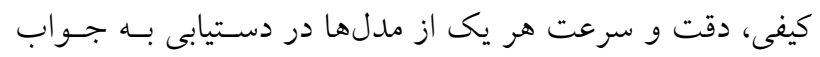

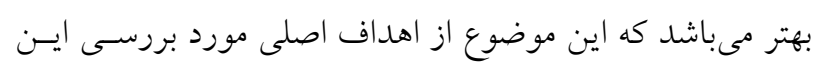

عمق متوسط سـفره آب زيرزمينسى اسـتفاده شــده اسـت. نتـايج

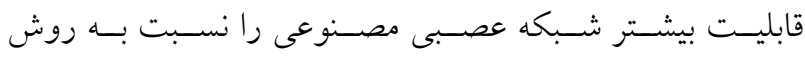
ركرسيون خطى جند متغيره نشان داده است. خز ايى و همكاران

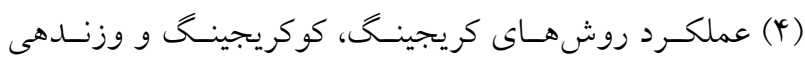

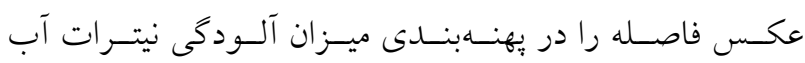

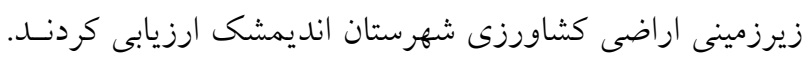

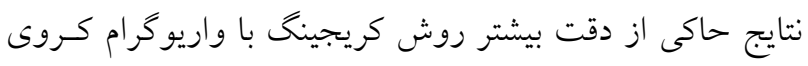

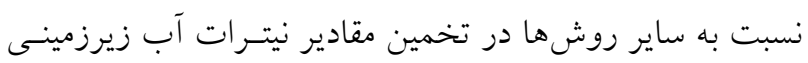

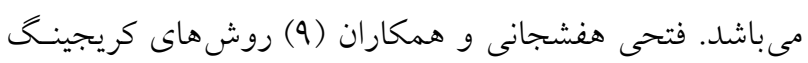

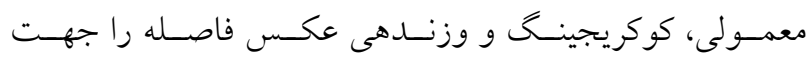

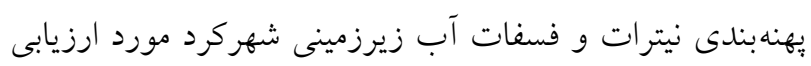

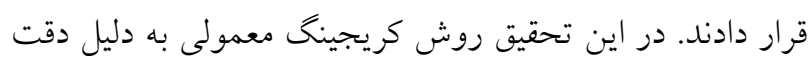
بيشتر، محاسبات كمتر و نياز به داده كمتر براى بهنهبندى نيترات و فسفات آب زيرزمينى شهركرد توصيه شده است.

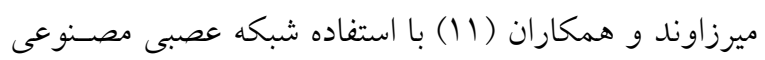

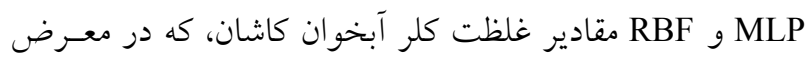

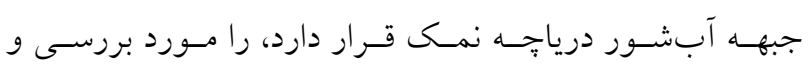

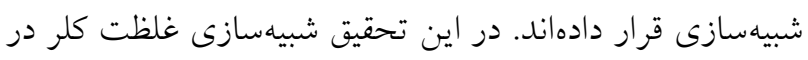

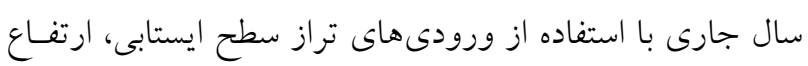
بارندگى ساليانه و غلظت كلر در سال قبل انجـام كرفتـه استـات.

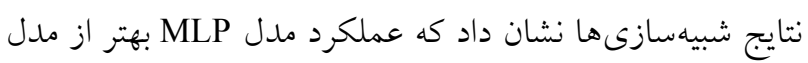

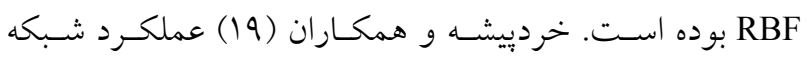
عصبى مصنوعى را در تخمين بارامترهاى كيفى

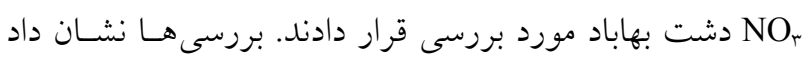

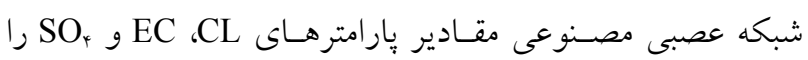

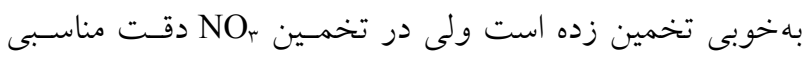
نداشته است.

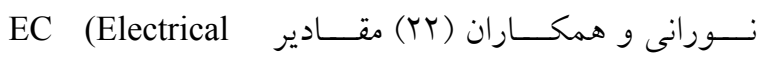
را TDS (Total Dissolved Solids) و Conductivity)

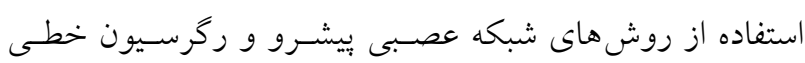

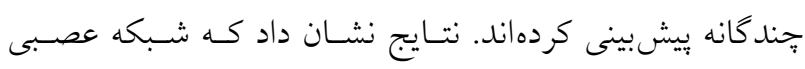

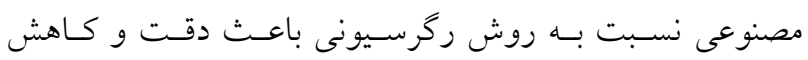




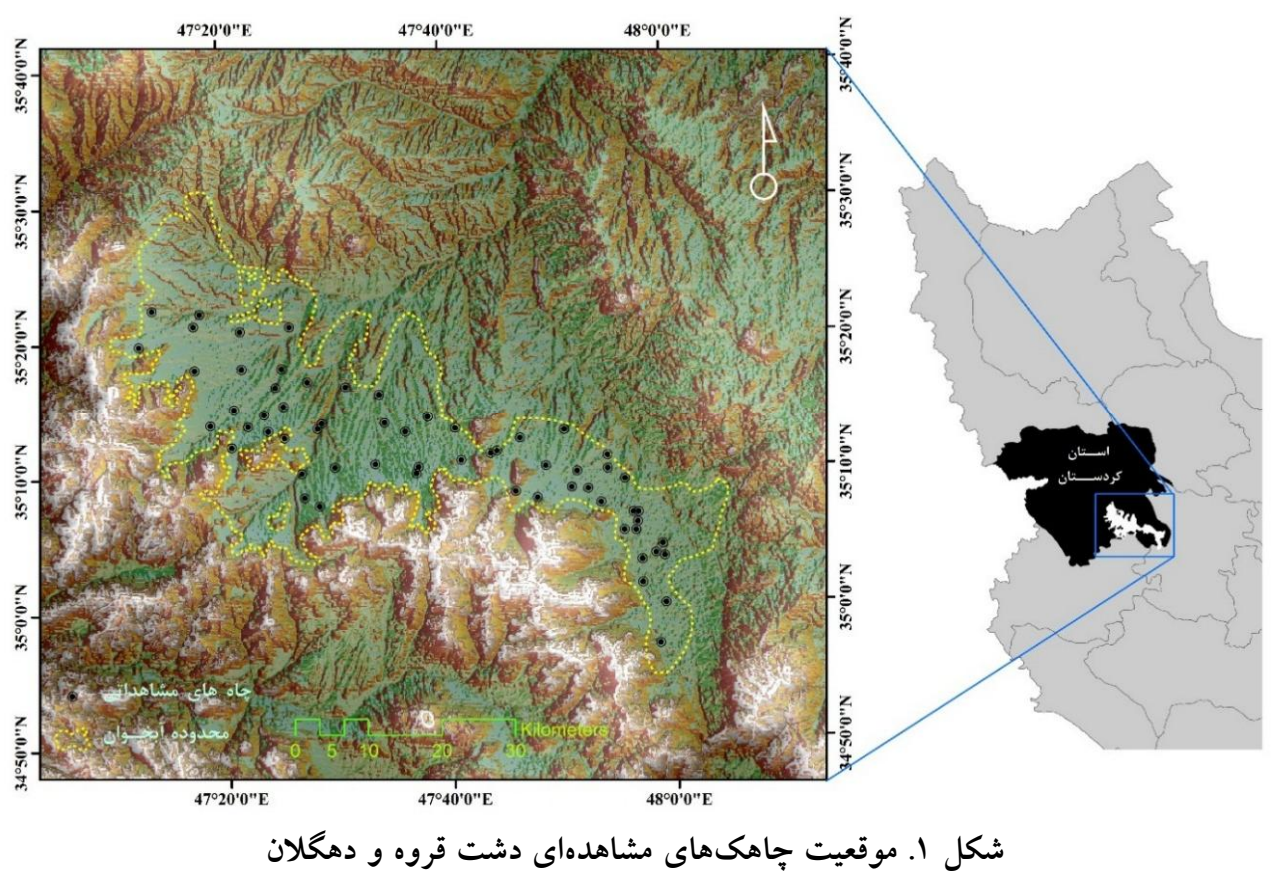

از مدلها، استفاده گرديلده است. موقعيت منطقه مورد مطالعـه و محل قرارگيرى جاهك هاى مشاهدهاى در شكل (1) نشـان داده شده است. قابل ذكر است كه جهت ارزيابى بهتر مدلهـا سـعى كرديد موقعيت جاهك هاى صحت سنجى يراكنـدگى خـوبى در سراسر منطقه داشته باشند.

نرمالسازى دادهها اولين گام در استفاده از روشهاى زمينآمارى بررسى نرمال بودن

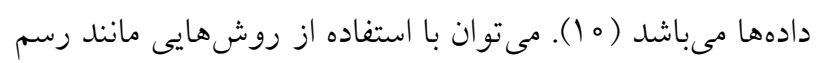
نمودارهاى فراوانى، بارامتر آمـارى ضـريب جــولكى، اسـتفاده از آزمونهاى آمـارى كلمـوكروف - اسـميرنف و شـاييرو - ويلـى لِّى

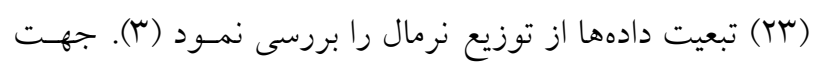

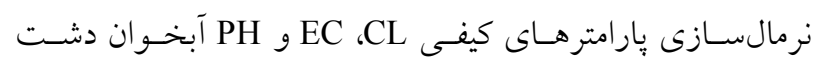
قروه-دهخلان، از روش باكس -كاكس استفاده كرديد.

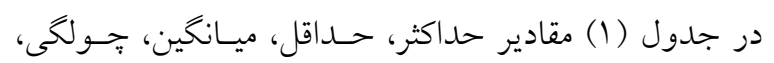

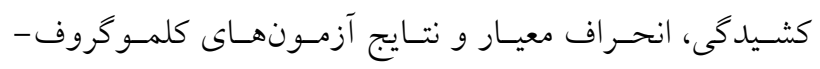
اسميرنف و شاييرو - ويلك براى دادههاى اصلى و نرمـال شـده در هر يك از دورههاى واسنجى و صـحت سـنجى آورده شــده
يزوهش بوده است. بدينمنظور دادههـاى كيفى CL و EC

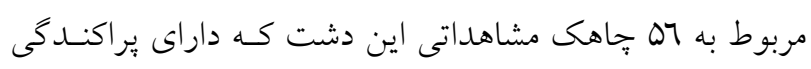
مناسبى هستند جهت انجام شبيهسازىهاى مربوط به هر يـك از مدلها انتخاب گرديدهاند. جهت ارزيابى بهتر كارايى مـدلهـاى زمين آمار، از روش هاى وزندهى معكوس فاصله و كريجينگ بـا جهار نوع واريو گرام كروى، دايرهاى، نمـايى و گوسسى استفاده

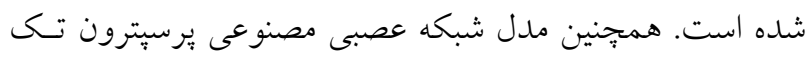
لايه با ا تا مب نرون در لايه ينهان جهـت تخمسين سـه بـارامتر كيفى مورد نظر به كار كرفته شد.

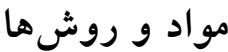
منطقه و دادههاى مورد استفاده در اين تحقيق از دادههاى هوه جاهـ مشاهدهاى واقع در دشـت قروه-دهخالان كه در جنوب شرقى استان كردستان واقع هستسند

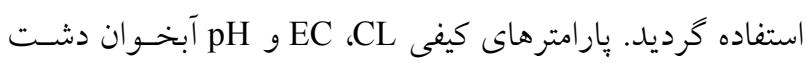
قروه-دهخالان كه مربوط به مهرماه سال موسا مى باشند بهعنوان ورودى مدلها در نظر كرفته شدهاند. هم:جنسين از دادههـاى

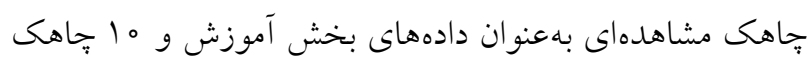
مشاهدهاى ديخر بهعنوان دادههاى بخش صحت سنجى هر يـى بـ بـ 
جدول ا. نتايج آزمون كلموكروف - اسميرنوف و شابيرو - ويلك براى دادههاى مشاهداتى اوليه و نرمالشده

\begin{tabular}{|c|c|c|c|c|c|c|c|c|c|c|c|c|}
\hline \multirow[b]{2}{*}{ يَارامتر } & \multirow[b]{2}{*}{ نوع داده } & \multirow[b]{2}{*}{ 京 } & \multirow[b]{2}{*}{$\frac{1}{\frac{1}{9}}$} & \multirow[b]{2}{*}{$\frac{1}{5}$} & \multirow[b]{2}{*}{$\begin{array}{l}\frac{\overline{1}}{9} \\
3 . \\
3\end{array}$} & \multirow[b]{2}{*}{$\nabla_{y}^{*}$} & \multirow[b]{2}{*}{$\begin{array}{l}3 \\
3: \\
4\end{array}$} & \multicolumn{3}{|c|}{ كلمو گروف - اسميرنوف } & \multicolumn{2}{|c|}{ شاييرو -ويلك } \\
\hline & & & & & & & & $\frac{\hat{\jmath}}{\frac{\hat{y}}{\hat{y}}}$ & $\frac{1}{3}$ & $\begin{array}{l}3 \\
2 \\
3 \\
3 \\
\frac{2}{y}\end{array}$ & $\frac{1}{3}$ & $\begin{array}{l}3 \\
3 \\
3 \\
\frac{3}{5}\end{array}$ \\
\hline \multirow{4}{*}{$\begin{array}{c}\mathrm{CL} \\
(\mathrm{mg} / \mathrm{l})\end{array}$} & مشاهداتى اوليه & $0 / T V$ & $0 / 09$ & $1 / 1 r$ & $0 / 19$ & T/A & $\mathrm{V} / \mathrm{Vq}$ & $\Delta G$ & $0 / 19$ & $\%$ & $\circ / V Q$ & $\circ / 00$ \\
\hline & 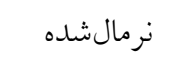 & $-Y / \Delta Y$ & $-Q / T \Delta$ & $\circ / T$ & $1 / T Y$ & $\circ / \circ \wedge$ & $-0 / 09$ & 09 & $\circ / \vee V$ & $\circ / r_{0}$ & $0 / 99$ & $\circ / N r$ \\
\hline & واسنجى & $-Y / 9 Y$ & $-Q / T Q$ & $0 / 1 \mathrm{~T}$ & $1 / T Y$ & $\circ / 14$ & $-0 / 4 t$ & is & .04 & $\circ / Y_{0}$ &.$/ 99$ &.$/ 91$ \\
\hline & صحت سنجى & $-T / 1 T$ & $-r / 91$ & $-0 / 4 \mu$ & $1 / Y_{0}$ & $-0 / 10$ & $-1 / Y Y$ & 10 &.$/ 14$ & $\circ / Y_{\circ}$ & $\circ / 90$ & $\circ / \mathrm{N}$ \\
\hline \multirow{4}{*}{$\begin{array}{c}\mathrm{EC} \\
(\mu \mathrm{mohs} / \\
\mathrm{cm})\end{array}$} & مشاهداتى اوليه & YYV/M & Ml\%o & $\Lambda \mu H / 0$ & $11 \Lambda / \mu Y$ & I/AT & $1 \% / 19$ & $\Delta 9$ & $\circ / Y_{0}$ & $\Delta 9 / 0$ & $\circ / \wedge 9$ & $\circ / 0 \circ$ \\
\hline & 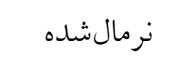 & $0 / 94$ & $0 / 94$ & $0 / 94$ & $\circ \% \circ$ & $\circ / 1 \circ$ & $1 / 04$ & 09 & $\circ / \wedge$ & $\Delta 9 / 0$ & $\circ / 91$ & $0 / 4$ \\
\hline & واسنجى & $0 / 94$ & $0 / 94$ & $0 / 94$ & $\circ \% \circ$ & .09 & $1 / 14$ & 49 & $\circ / \circ \mathrm{V}$ & $\circ / r_{0}$ & $\circ / 91$ & $0 / 99$ \\
\hline & صحت سنجى & $0 / 94$ & $0 / 94$ & $0 / 94$ & $\circ \% \circ$ & ( ) & $0 / 91$ & 10 & $0 / 19$ & $\circ / Y_{0}$ &.$/ 94$ & ./Qr \\
\hline \multirow[t]{4}{*}{$\mathrm{pH}$} & مشاهداتى اوليه & $V / 99$ & G/VQ & $\Lambda / \mu \omega$ & 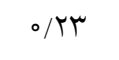 & $-Y / V G$ & $1 \% / \wedge 9$ & $\Delta 9$ & $\circ / 1 \wedge$ & $\circ / 0$ & $\circ / \mathrm{VA}$ & $\circ / 00$ \\
\hline & نرمالشده & $1 \pi E+\theta$ & $r r E+r$ & $11^{*} E+1$ & $1 r E+r$ & 。 & 1 & $\Delta S$ & .09 & $\circ / Y_{0}$ & $\circ / 9 V$ & $\circ / Y \wedge$ \\
\hline & واسنجى & $\pi \mathrm{E}+\phi$ & $1 \mu E+r$ & $14 E+1$ & $1 r E+r$ & 。 & 1 & is &.$/ 11$ & $\circ / Y_{0}$ & $0 / 99$ & $\circ / 14$ \\
\hline & صحت سنجى & $r_{E}+\varphi$ & $r E+r$ & $1 r E+v$ & $1 r E+r$ & 。 & 1 & 10 & $0 / \pi \mu$ & $0 / 10$ & $\circ / \wedge \mathrm{V}$ & $0 / 09$ \\
\hline
\end{tabular}

مقايسه با ايستخاههاى دورتر داده مىشود. در زير به توضيح اين دو روش يرداخته شده است.

\section{روش كريجينگ}

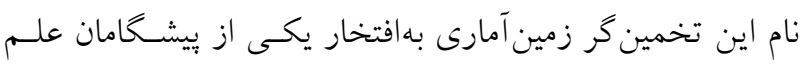

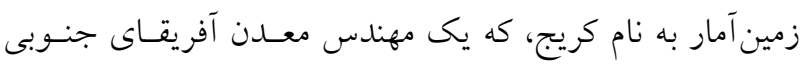

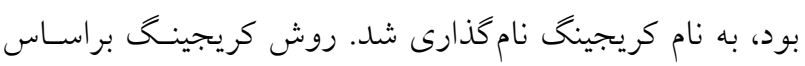

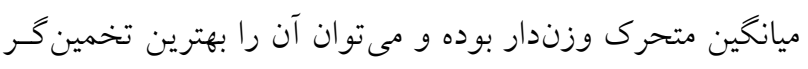

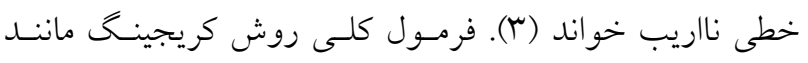

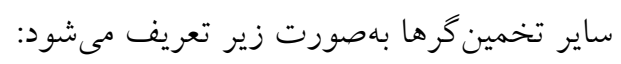

$\mathrm{z} *(\mathrm{xi})=\sum_{\mathrm{i}=1}^{\mathrm{n}} \lambda \mathrm{iZ}(\mathrm{xi})$

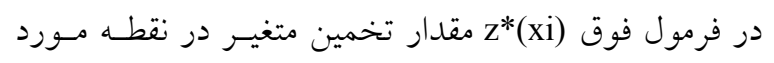

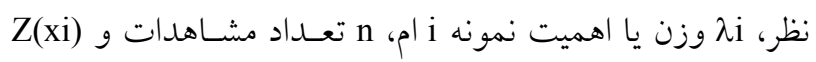

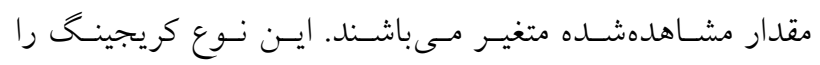

روشهاى تخمين در زمين آمار

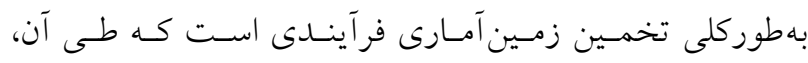

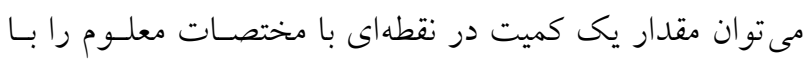

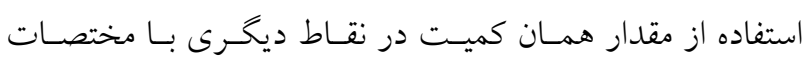

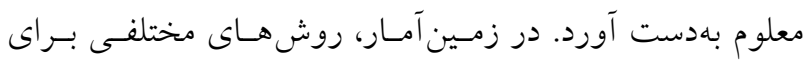

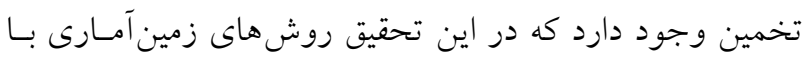

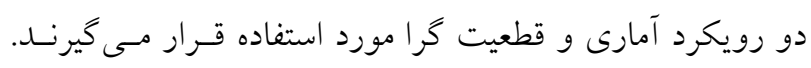

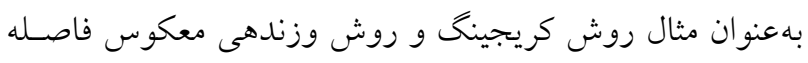

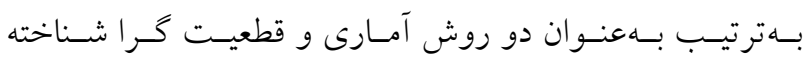

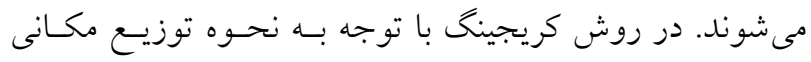

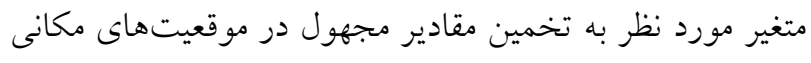

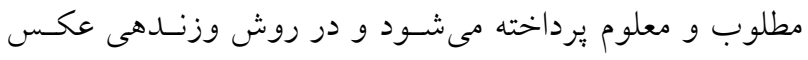

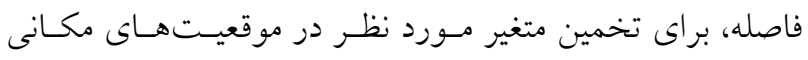

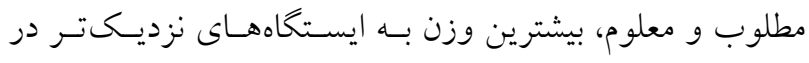




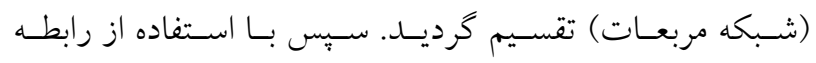

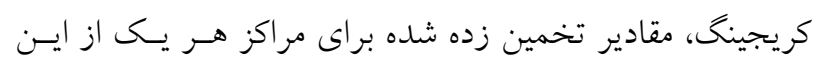
سلولها محاسبه كرديد.

\section{مدلهاى تئورى واريو گرام}

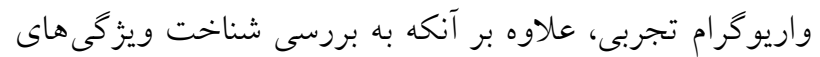

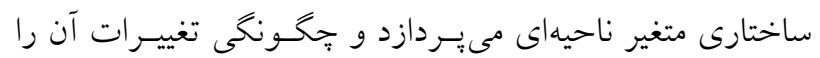

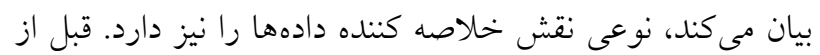

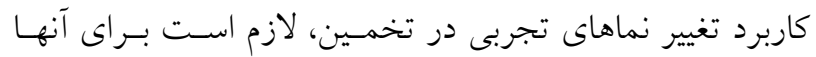

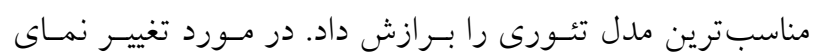

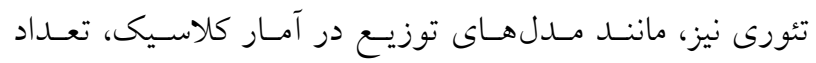

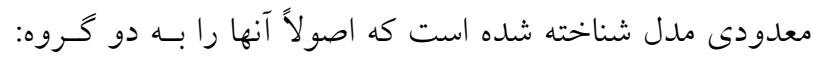
فاقد آستانه و داراى آستانه تقسيم مى كند. در خروه فاقد آستانه با افزايش فاصله h، مقدار تغييرنمـا نيـز

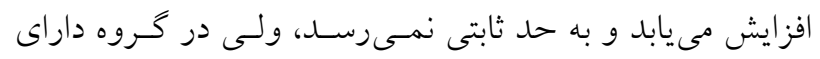

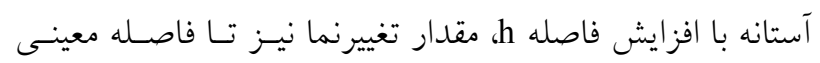

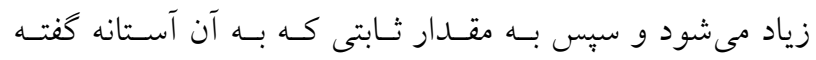

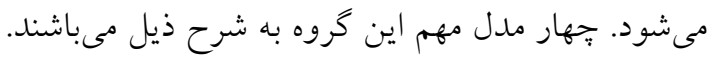

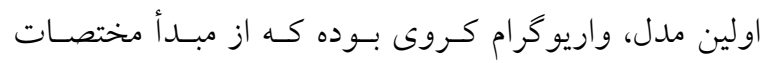

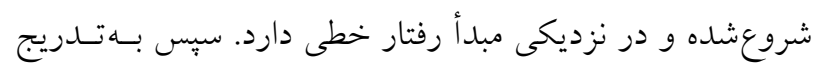

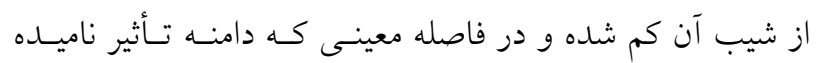

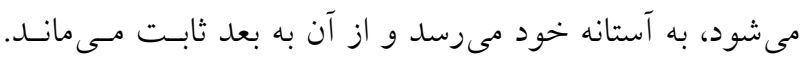

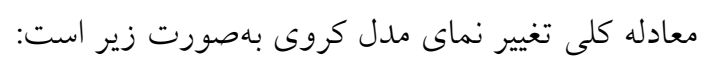

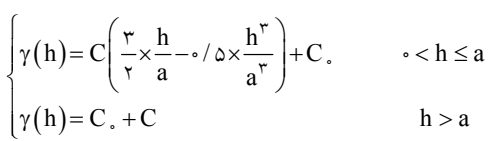
كه در آن C آستانه، a دامنه تأثير، . C اثر قطعهاى مسىباشــد. در عمل دامنه تأثير براى مدل كروى

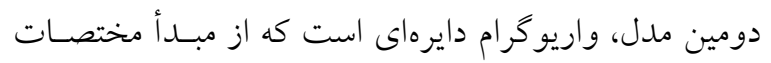

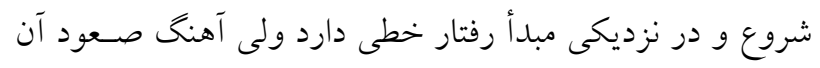
كمى آرامتر از مدل كروى است.

$\left\{\gamma(\mathrm{h})=\mathrm{C}\left(1-\frac{r}{\pi} \cos ^{-1}\left[\frac{\mathrm{h}}{\mathrm{a}}\right]+\sqrt{1-\left[\frac{\mathrm{h}^{\mathrm{r}}}{\mathrm{a}^{r}}\right]}\right)+\mathrm{C}_{\mathrm{o}} \quad \cdot<\mathrm{h} \leq \mathrm{a}\right.$ $[r]$ $\gamma(\mathrm{h})=\mathrm{C}_{\mathrm{o}}+\mathrm{C} \quad \mathrm{h}>\mathrm{a}$

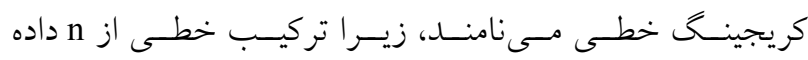

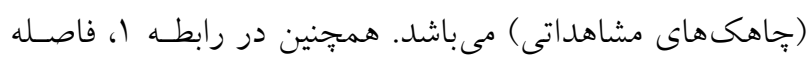

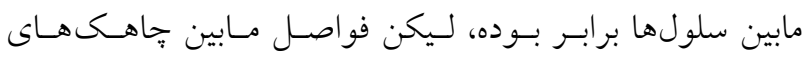

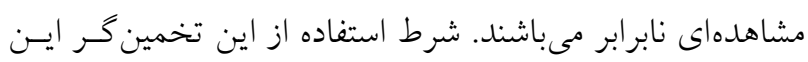

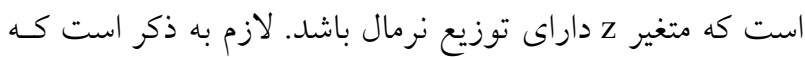

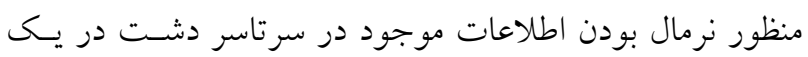

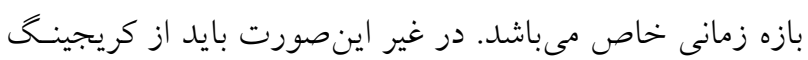
غيرخطى استفاده كرد و يا اين كه بهنحوى توزيـع متغيرهـا را بـهـ

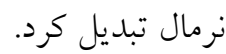
واريانس ارتفاع ميان نقاط كه بهاندازه h از هم فاصله دارنــد،

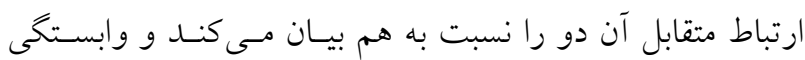

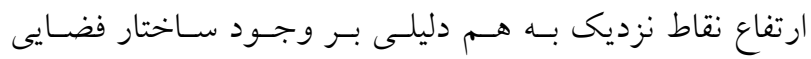

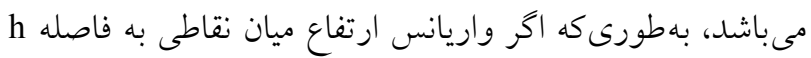

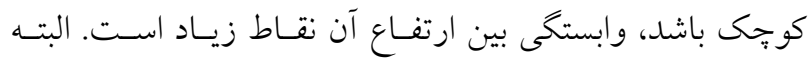

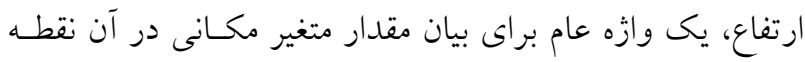

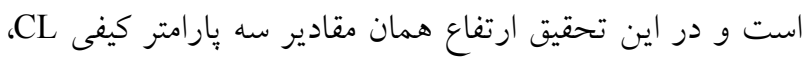

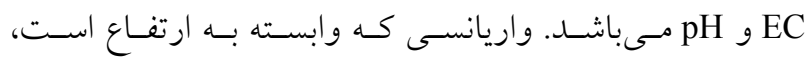

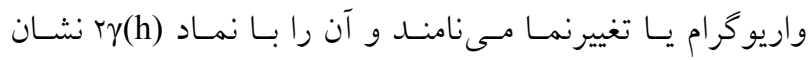

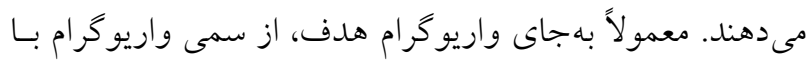

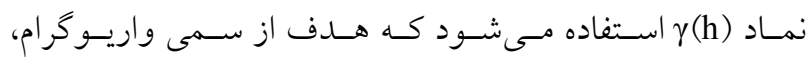

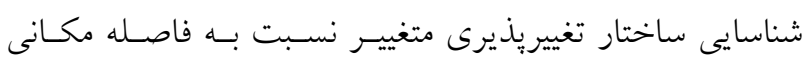

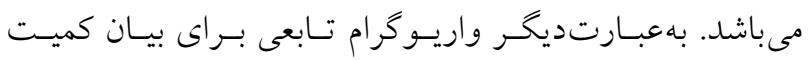

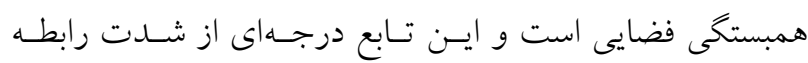

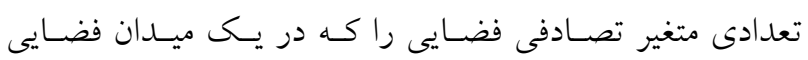

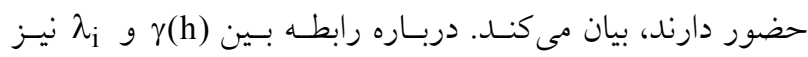

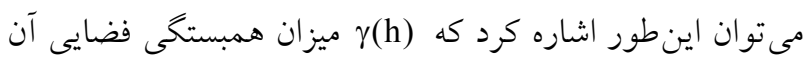

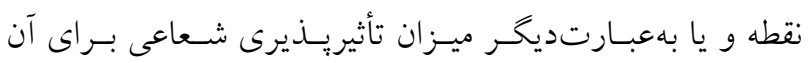

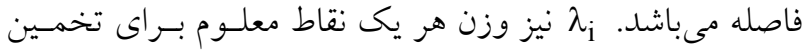
مقدار در نقطه نامعلوم مى باشد. براى تعيين اين وزنها معادلات

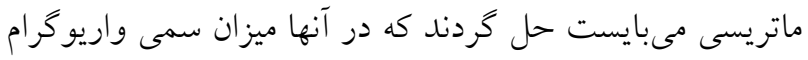

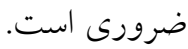
لازم بهذكر است، دشـت مـورد مطالعـه بـهـ تعـدادى سـلول 
ارزش آن نامعلوم است با استفاده از نقاط اطراف در يك شـعاع مشخص براساس فرمول زير برآورد مىشود: $\mathrm{Z}(\mathrm{xi})=\sum_{\mathrm{i}=1}^{\mathrm{N}} \lambda_{\mathrm{i}} \mathrm{z}(\mathrm{xi})$

كه در آن z(xi) ارزش معلوم نقاط بـا مختصـات معلسوم، Na

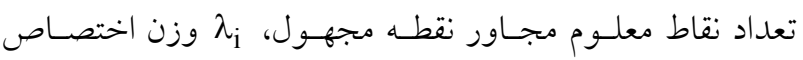

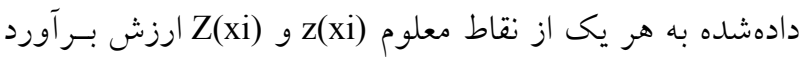
شده نقطه مجهول مى باشد. جِون مقدار

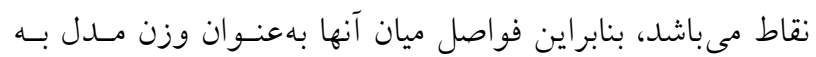

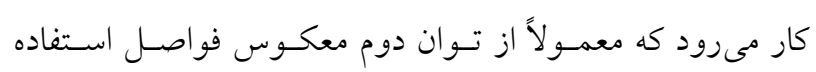
مىشود و براى وزن فواصل مقدار توان افزايش مى يابد.

شبكههاى عصبى ييشرو با آموزش لونبرى-ماركوارت

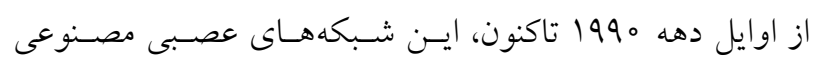

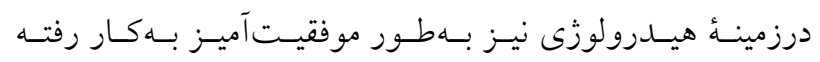

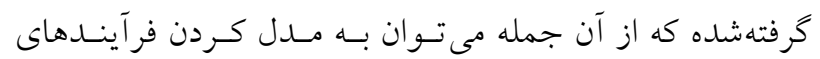

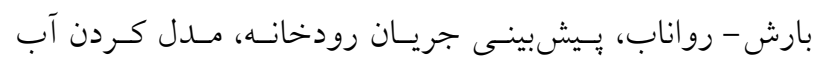

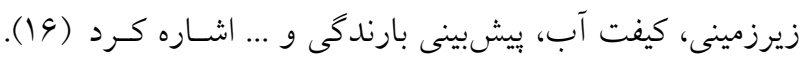

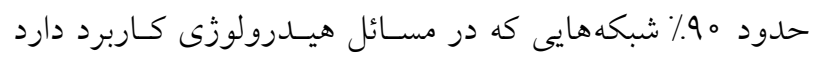

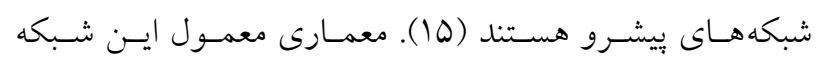

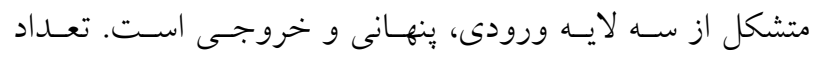

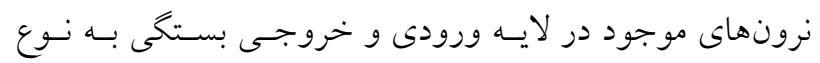

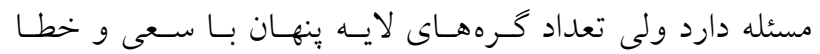

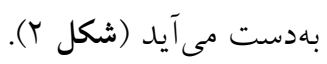

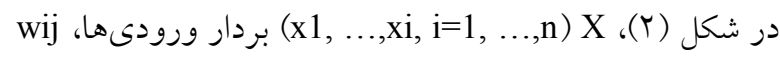
وزن اتصالى از i امين گره به j امين گَره در لايه بعد، bj بايساس

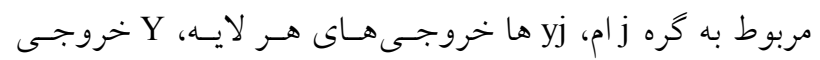

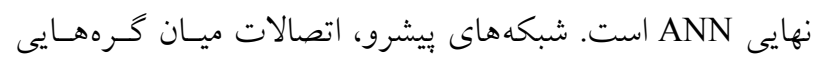

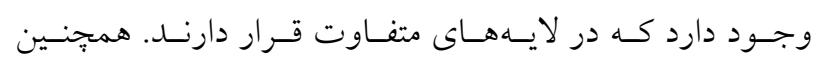

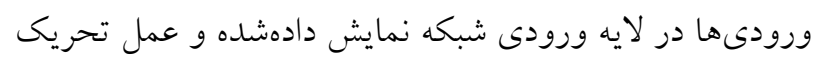

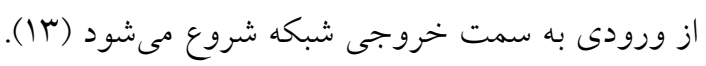

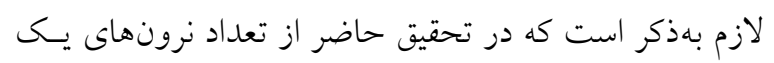

مدل نمايى نيز مانند مدل كروى از مبدأ مختصات شـروع و

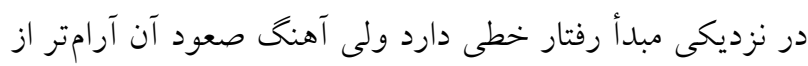
مدل كروى است.

$\gamma(\mathrm{h})=\mathrm{C}\left(1-\exp \left[-\frac{\mathrm{h}}{\mathrm{a}}\right]\right)+\mathrm{C}_{\mathrm{o}} \quad \mathrm{h}>0$ جهارمين مدل واريوكرام كوسى است، منحنى مربوط به اين

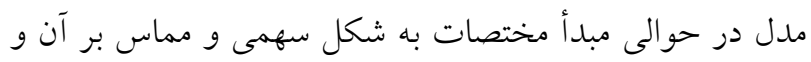

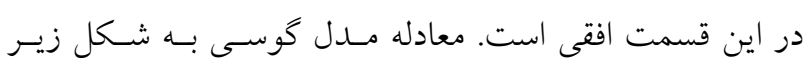

$\gamma(\mathrm{h})=\mathrm{C}\left(1-\exp \left[-\frac{\mathrm{h}^{r}}{\mathrm{a}^{r}}\right]\right)+\mathrm{C}_{\mathrm{o}}$

در ايـن تحقيـق مراحـل كلـى اجـــاى درونيـابى بـا روش

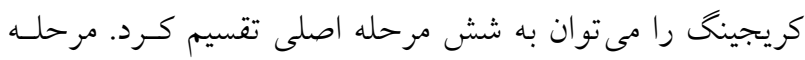
اول: بررسى تبعيت توزيع دادههاى مورد استفاده از توزيع نرمال

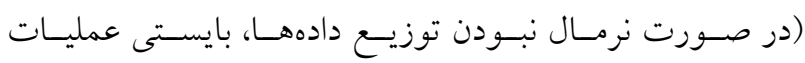

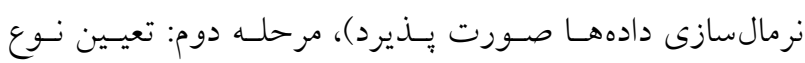

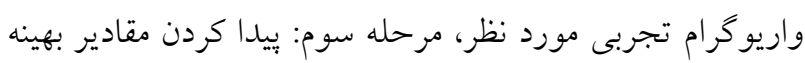

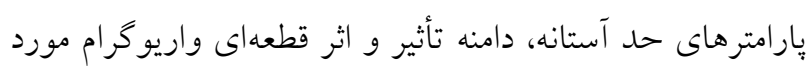

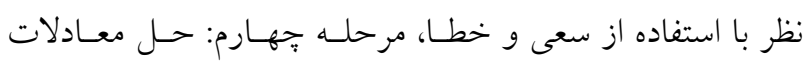

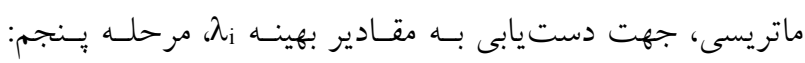

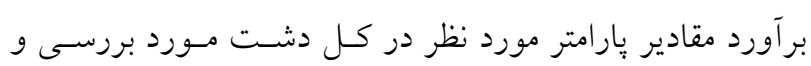

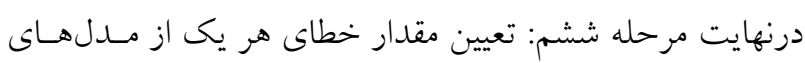

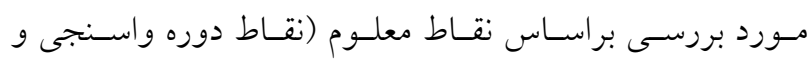
صحت سنجىى).

\section{روش وزندهى عكس فاصله}

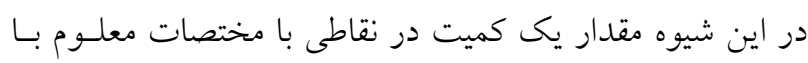

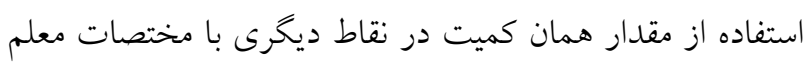

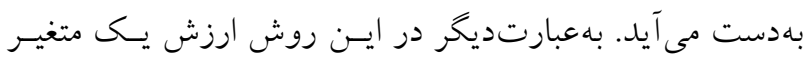

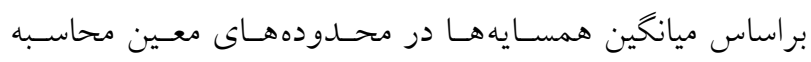

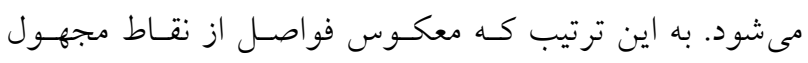

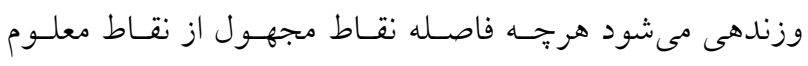

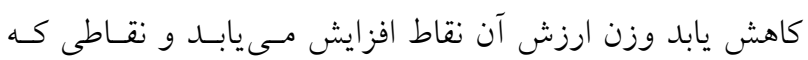




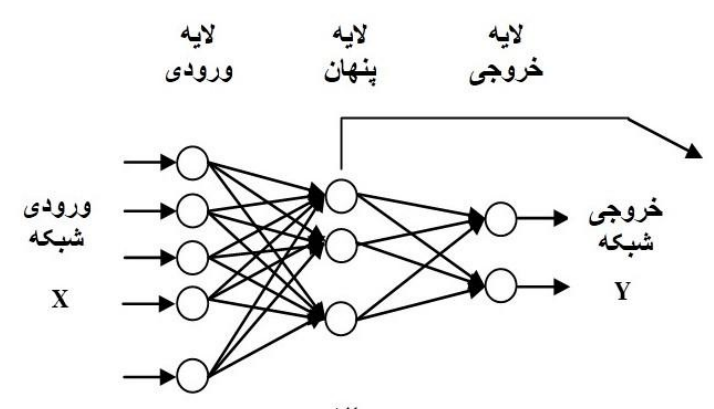

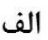

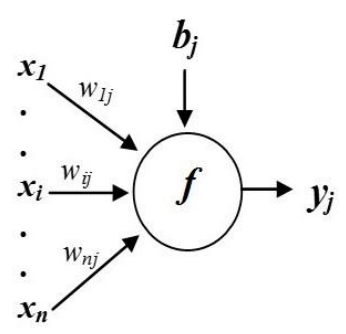

ب

شكل r . الف) شماى كلى شبكهاى بيشرو سه لايه، ب) شماى j ام گره از آن (II)

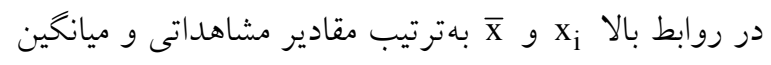

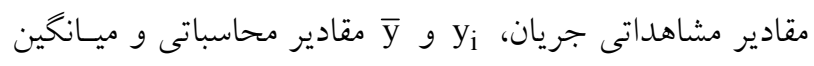
مقادير محاسباتى و N تعداد دادههاى جريان مىباشد

\section{روش انجام تحقيق}

هدف تحقيق بسط و تهيه مدلهايى مىباشد كـه بـهوسـيله آنهـا

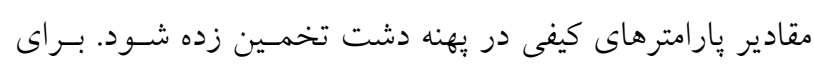

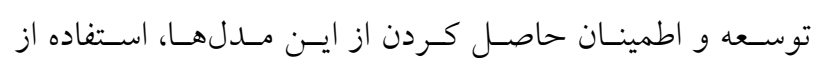

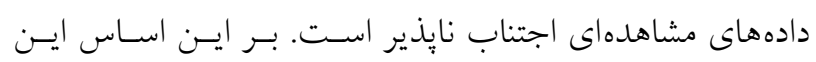

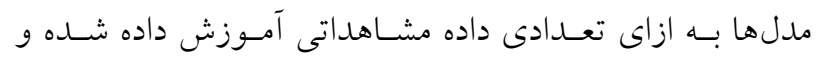
سبس براى دادهاى صحت سنجى مورد استفاده قرار مى گيرند.

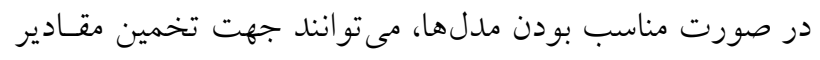

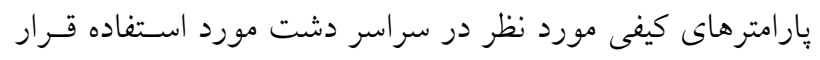

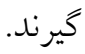

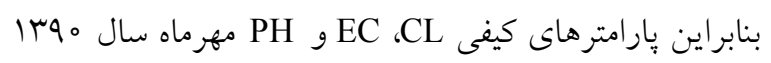

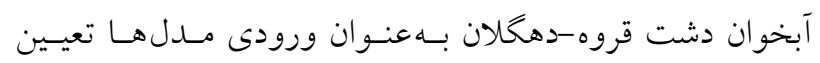

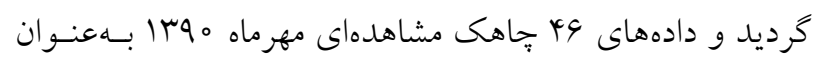
بخش آموزش و دادههاى ه إخاهك مشاهدهاى ديخر در مهرماه

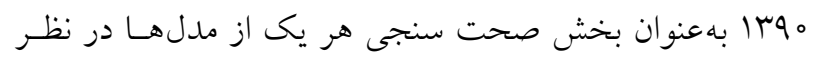

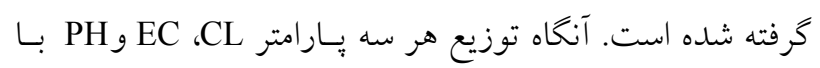

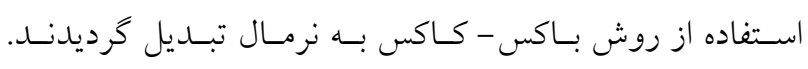

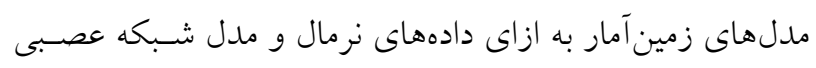

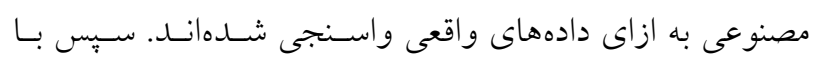

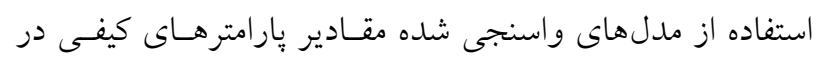

تا ب ب براى لايه بنهان شبكه استفاده گرديد تا از ايـن طريـق

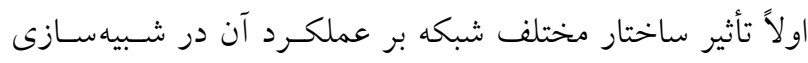

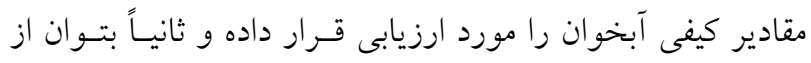

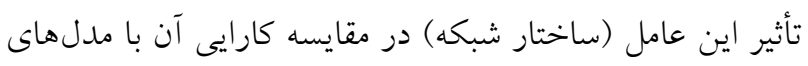

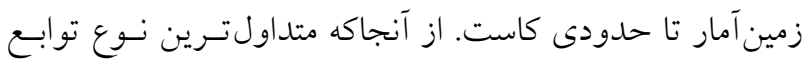

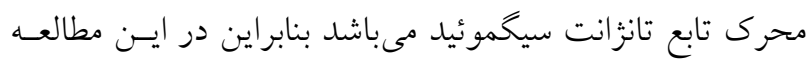

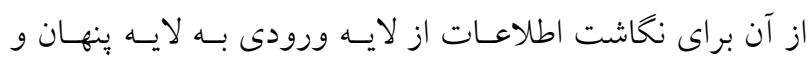

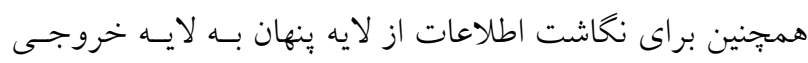

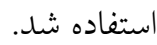

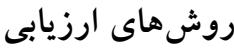

با استفاده از روشهاى مختلفى مىتوان عملكرد مدلها را مورد

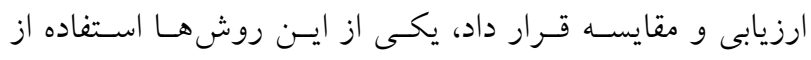

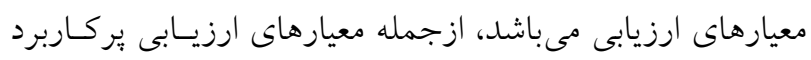

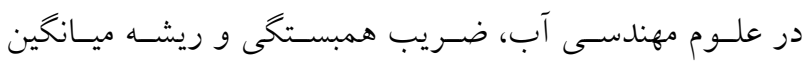

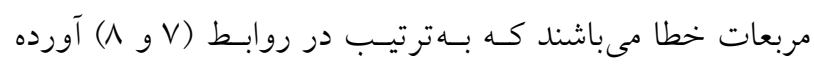

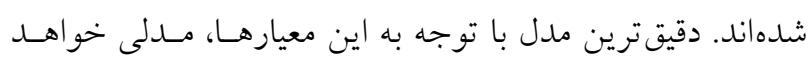

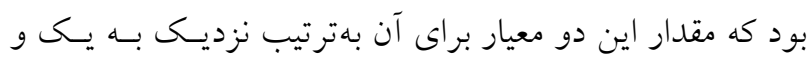

$$
\begin{aligned}
& C C=\frac{\left(\sum_{i=1}^{N}\left(x_{i}-\bar{x}\right)\left(y_{i}-\bar{y}\right)\right)^{r}}{\sqrt{\sum_{i=1}^{N}\left(x_{i}-\bar{x}\right)^{r}} \sqrt{\sum_{i=1}^{N}\left(y_{i}-\bar{y}\right)^{r}}} \\
& \text { RMSE }=\sqrt{\frac{1}{N} \sum_{i=1}^{N}\left(x_{i}-y_{i}\right)^{r}}
\end{aligned}
$$
صفر باشد. 
جدول Y. نتايج تخمين يارامترهاى CL و EC ب PH استفاده مدلهاى شبكه عصبى،IDW و Kriging

\begin{tabular}{|c|c|c|c|c|c|c|c|}
\hline \multicolumn{2}{|c|}{$\mathrm{PH}$} & \multicolumn{2}{|c|}{$\mathrm{EC}$} & \multicolumn{2}{|c|}{ CL } & & \multirow{2}{*}{ 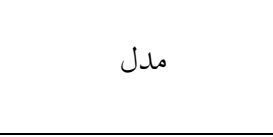 } \\
\hline $\mathrm{CC}$ & RMSE & $\mathrm{CC}$ & $\begin{array}{c}\text { RMSE } \\
(\mu \mathrm{mohs} / \mathrm{cm})\end{array}$ & $\mathrm{CC}$ & $\begin{array}{l}\mathrm{RMSE} \\
(\mathrm{mg} / \mathrm{l})\end{array}$ & & \\
\hline $0 / 19$ & $\circ / \mathrm{V}$ & o/A & $111 / 1 r$ & $\circ / 1 \mathrm{~V}$ & $0 / 19 \circ$ & train & \multirow[b]{2}{*}{ Kriging(circular) } \\
\hline$\circ / 09$ & $0 / \pi q$ & $\circ / \Delta V$ & $\Lambda V / 90$ & $0 / 491$ & $\circ / \backslash \wedge \mathrm{V}$ & test & \\
\hline $0 / 19$ &.$/ \mathrm{V}$ & o/^r & $110 / \pi r$ & $\circ / 1 \mathrm{~V}$ & $0 / 1 \wedge 4$ & train & \multirow[b]{2}{*}{ Kriging(spherical) } \\
\hline $0 / 9 \circ$ & $0 / 4 q$ & $0 / 90$ & $\Lambda q / 4\rangle$ &.$/ 491$ & $\circ / I V V$ & test & \\
\hline$\circ / I V$ & $0 / \mathrm{IV}$ & $\circ / \mathrm{VA}$ & $109 / 90$ & سואו & $0 / 111$ & train & \multirow[b]{2}{*}{ Kriging(exponential) } \\
\hline $0 / 91$ & $0 / \pi q$ & o/Ar & $9 \circ / 00$ & .1094 & $0 / 191$ & test & \\
\hline$\circ / 1 \Lambda$ & $\circ / I V$ & $\circ / \mathrm{VA}$ & $10 N / 94$ & 。 & $\circ / 1 \wedge \circ$ & train & \multirow[b]{2}{*}{ Kriging(gussian) } \\
\hline$\circ / 09$ & $\circ / x_{0}$ & $\circ / 01$ & $\| T / V D$ & $0 / 91 Y$ & $0 / 199$ & test & \\
\hline $1 / 00$ & $\circ / 00$ & $1 / 00$ & O TY & $1 / 000$ & $\circ / 000$ & train & \multirow[b]{2}{*}{ IDW } \\
\hline $0 / 9 \Lambda$ & $\circ / \pi \Delta$ & $0 / 91$ & $100 / 10$ & $\circ / 4 \vee 0$ & $0 / 190$ & test & \\
\hline$\circ / 4 \Delta$ & $0 / 19$ & $\circ / \Delta \Delta$ & $91 / \circ 4$ & $\circ / \Delta V Y$ & \% & train & \multirow{2}{*}{ ANN } \\
\hline$\circ / \Delta \wedge$ & $\circ / \mu Y$ & $\circ / \vee$ & $90 / 90$ & -NGY & $0 /|4|$ & test & \\
\hline
\end{tabular}

آبخوان دشت قروه - دهخلان مورد ارزيابى قـرار كرفتـه اسـت. نتايج مربوط به شبيهسازى هـر يـى از مـدلهـا در جـدول (Y) نشان داده شده است و در ادامه نتايج هر يكى از مدلها بررسى

$$
\text { مى كردد. }
$$

\section{روش كريجينگ}

نتايج تخمين يارامترهاى CL، EC و PH در دورههاى واسـنجى و صحت سنجى بهوسيله مدلهاى كريجينگ دايسرهاى، كـروى، نمـايى و كوسـى در جــدول (Y) نشـان داده شـده اسـت. مــدل كريجينگ با سمى واريوگرام كروى دقت بيشترى نسبت به ساير مدلهاى كريجينگ، شبكه عصبى و IDW در تخمين پارامتر EC داشته است. مقاديرRSE و RC اين مدل در تخمسين پـارامتر

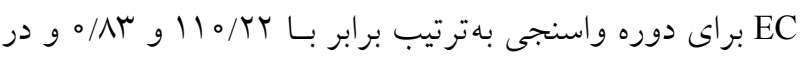

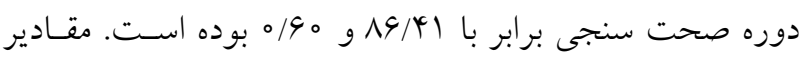
مشاهداتى و محاسبه شده در هر يك از تحاهكهـا بـا مـدل EC كريجينگ كروى در شكل (r) نشان داده شده است. با توجه بـه نتايج جدول (Y) ديلده مىشود كه مدل كريجينگ كوسسى دقت
محل نقاط واسنجى و صحت سنجى بهدست آمده است. يّ از بازگردانى مقادير محاسباتى هر يك از مــدلهـا بـه حالـت غيـر نرمال (عكس روش باكس - كاكس)، مقادير ضريب همبستخى و ريشه ميانخين مربعات خطا براى هر دو دوره واسنجى و صحت سنجى محاسبه كرديل. سبس با توجه به ايسن ضـرايب عملكـرد هر يك از مدلها مورد ارزيابى و مقايسه قرار گرفته است. لازم بهذكر است كه در روش كريجينگ بهترين قيارامترهـاى

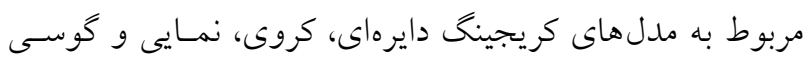
در نرمافزار GIS بـا سـعى و خطـا در سـمى واريـو گرام تعيسين

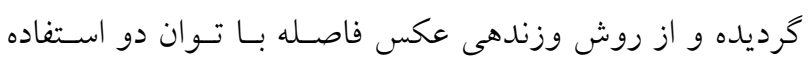
شده است. هم:جنين از شبكه عصـبى مصسنوعى بـه ازاى تعـداد نرونهاى ا تا مب و تـابع محسرى تانزانـت سـيخموئيد در لايـه ينهان جهت شبيهسازىها استفاده گرديده است.

\section{نتايج و بحث}

جنانجه ذكر گرديل، در اين تحقيق عملكرد روشهاى زمين آمـار و شبكه عصبى مصنوعى در تخمين مقـادير سـه يـارامتر كيفى 


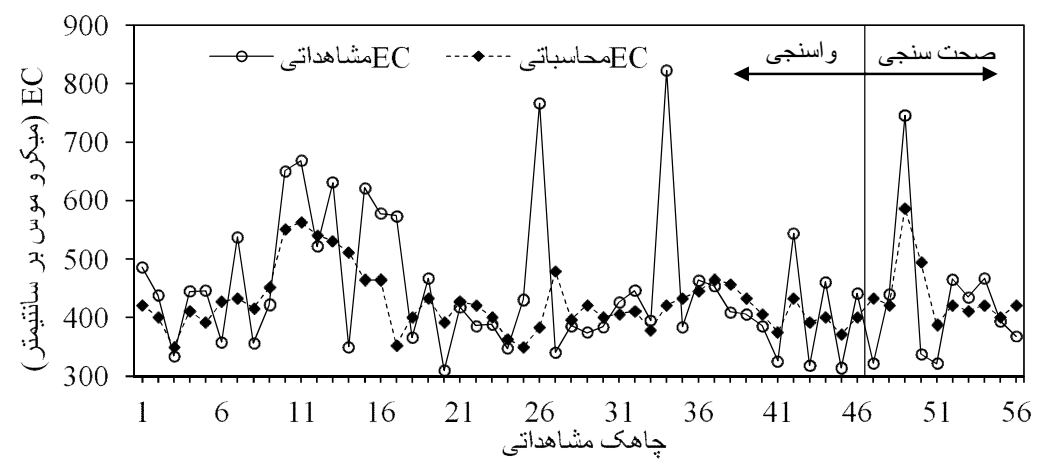

شكل r. مقادير EC مشاهداتى و محاسباتى با روش كريجينگ كروى در دورههاى واسنجى و صحت سنجى

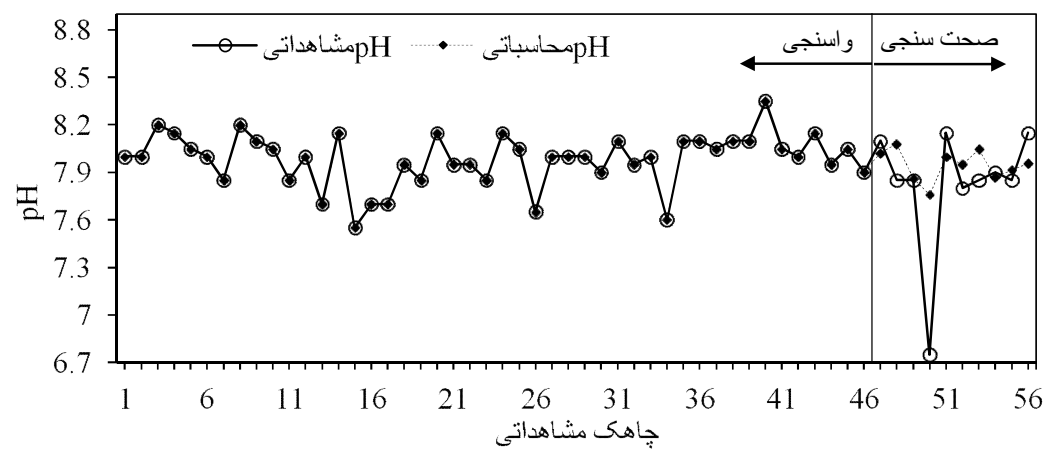

شكل f. مقادير pH مشاهداتى و محاسباتى با روش IDW در دورههاى واسنجى و صحت سنجى

روش IDW در جدول (Y) نشان داده شده اسـت. بـا توجـه بـهـ مقادير پارامترهاى اين جدول مشاهده مسى شـود كـه ايـن روش

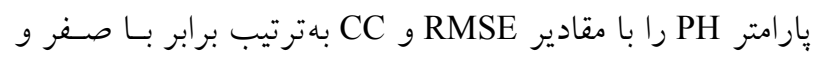

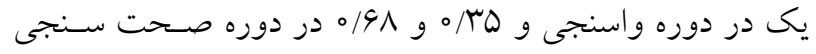
بهتر از ساير مدلهاى كريجينـ و شـبكه عصسبى تخمسين زده ورها

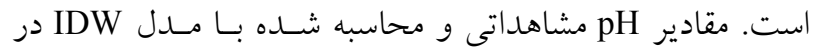

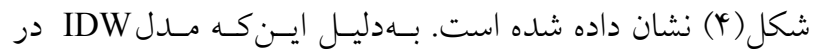
دوره واسنجى صفحه مورد نظر را از مقادير نقاط مورد استفاده

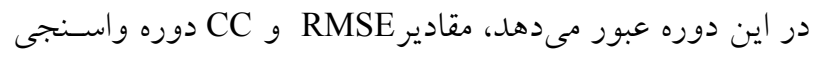
بهترتيب برابر صفر و يكى مىباشد.

\section{روش شبكه عصبى مصنوعى}

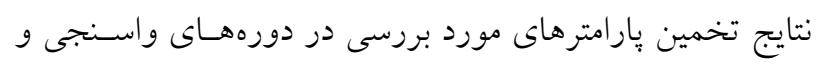

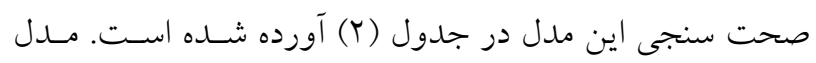

بيشترى نسبت بـه سـاير مـدلهـاى كريجينـع در تخمسين مقـدار

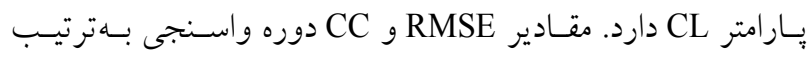

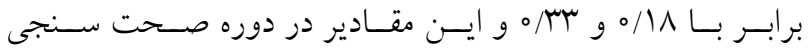

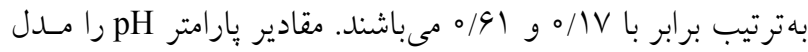

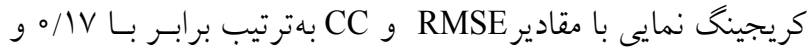

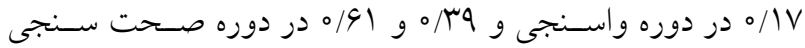
بهتر از ساير مدلهاى كريجينگ تخمين زده اسـت. البتـه اخـتلاف

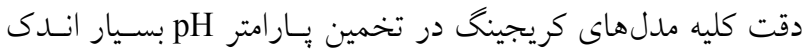

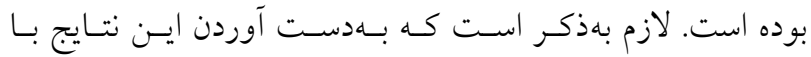

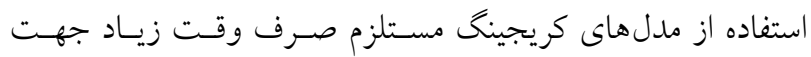
بهينه كردن بار امترهاى سمىواريو گرام مىباشد.

روش وزندهى عكس فاصله

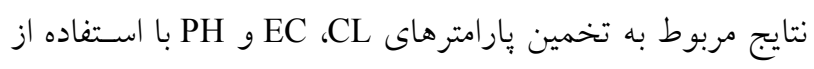




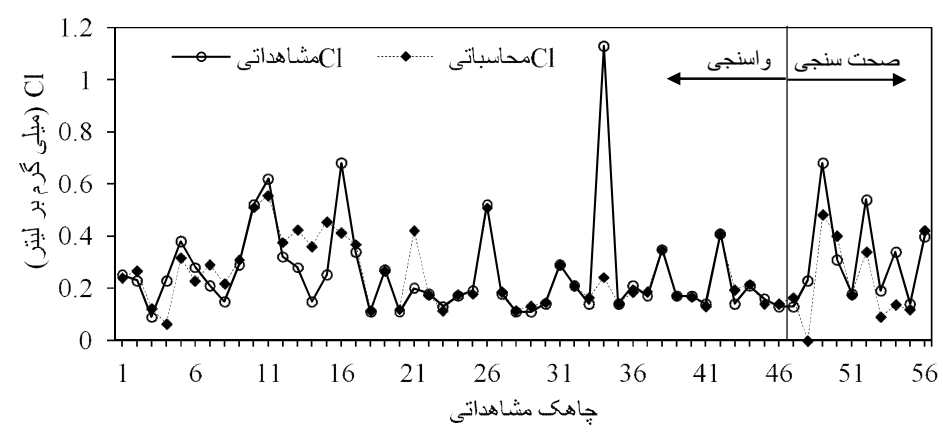

شكل ه. مقادير CL مشاهداتى و محاسباتى با مدل شبكه عصبى مصنوعى در دورههاى واسنجى و صحت سنجى

داراى دقـت بيشـتر از سـاير مـدلهـاى كريجينـخ مسىباشــ و اختلاف بسيار كمى نسبت به روش IDW دارد و ايـن مــدل در

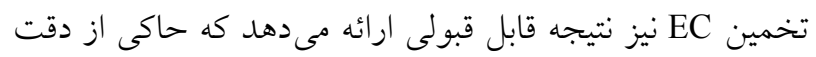

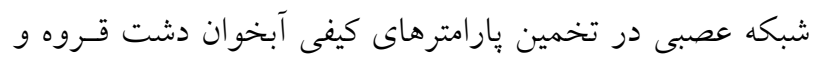

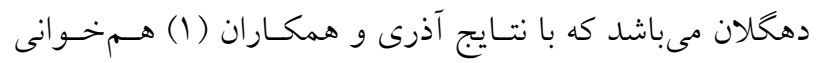

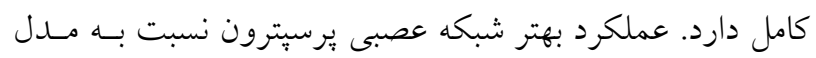

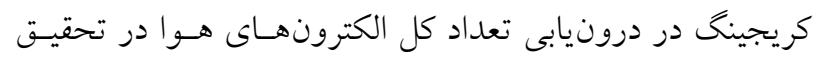

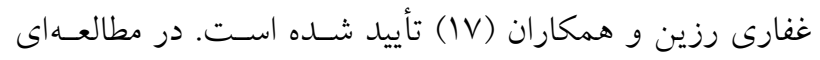

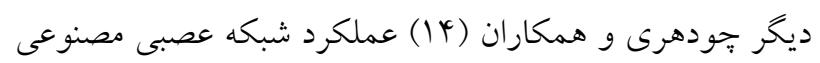

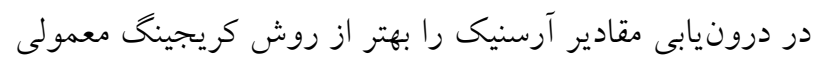

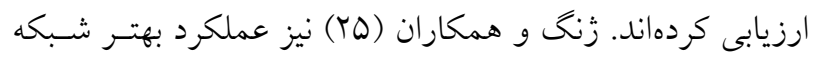

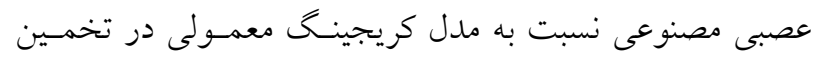

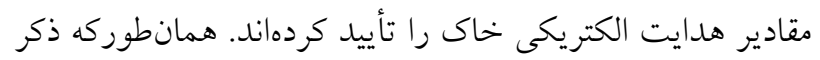

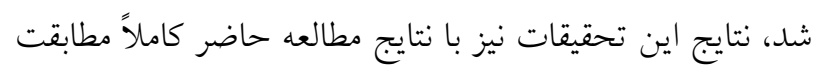
دارد.

همجنِنين جهت دستيابى به بهترين نتيجه از روش كريجينـ

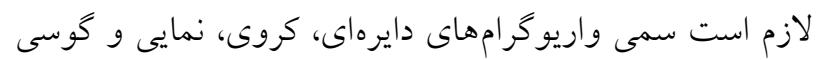

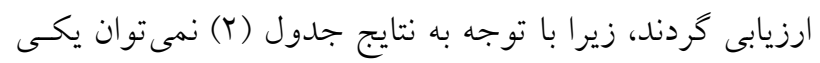

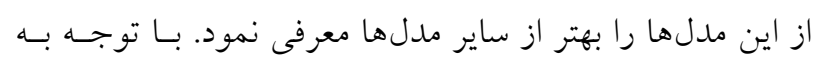

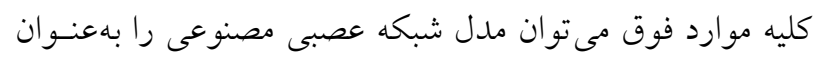

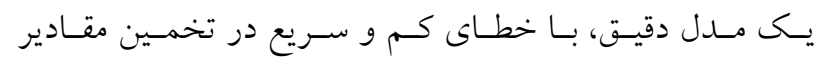
يار امترهاى كيفى آبخوان دشت قروه- دهخلان معرفى نمود.
شبكه عصبى تو انسته است عملكرد بهترى نسبت به ساير مدلها براى تخمين بيارامتر CL داشته باشد. مقادير RMSE و CC ايسن

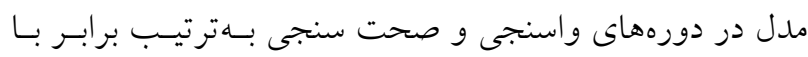

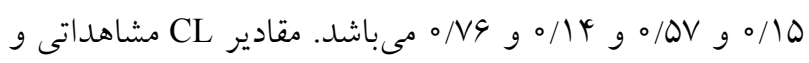

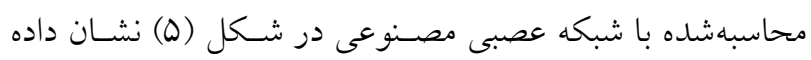

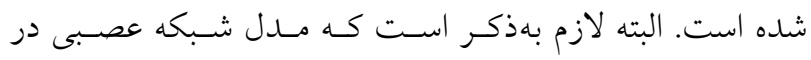

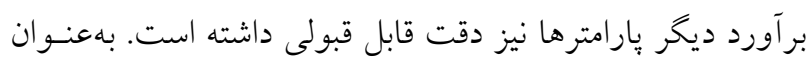

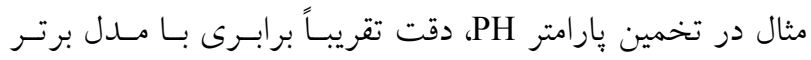
IDW است. همجِنين اين مدل در تخمين پارامتر EC نيـز دقـت قابـل قبولى داشته است.

\section{نتيجه گيرى}

روشهاى مختلفى جهت برآورد بارامترهاى كيفى آبخوان وجود

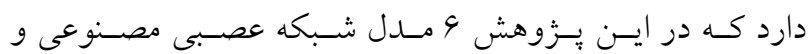
روش هاى زمين آمار IDW، كريجينگ دايرهاى، كروى، نمـايى و و

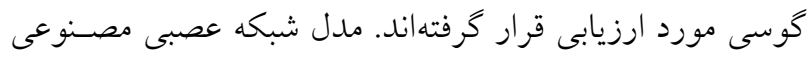

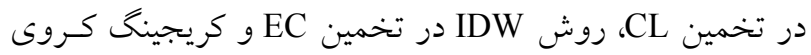
در تخمين pH نتايج بهترى نسبت به ساير مدل داشـتهانـد. لازم ردمئ

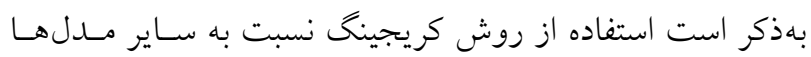

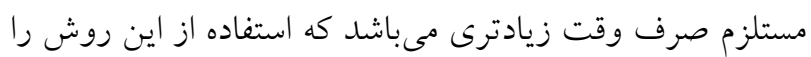
در مواقع كمبود وقت دجار مشكل مى كند. بـا توجـهـ بـه نتـايج

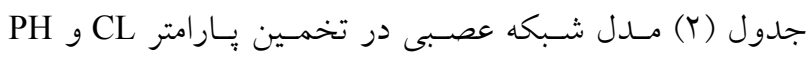




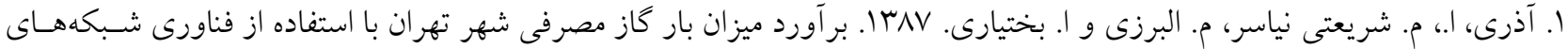

$$
\begin{aligned}
& \text { عصبى. نشريه دانشكده فنى دانشخاه تهر ان r) } \\
& \text { ז. بانزاد، ح.، ح. محبز اده و ا. عليائى. } \\
& \text { كشت (مطالعه موردى :شهرستان نهاوند). علوم و تكنولوزى محيط زيست ها( (1): ه广-بr. }
\end{aligned}
$$

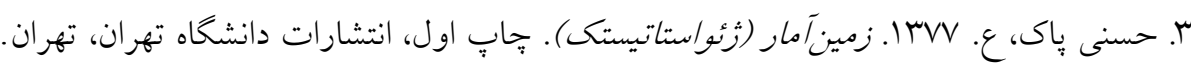

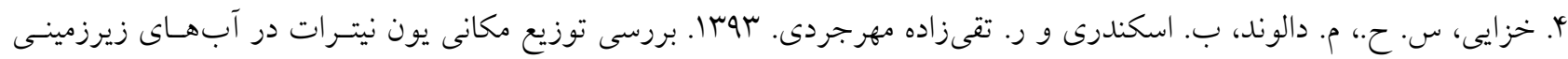$$
\text { شهرستان انديمشك با استفاده از روشهاى زمين آمارى. مجله محيط زيست طبيعى، منابع طبيعى ايران }
$$$$
\text { ه. رحيمى، ق.، و ا. جرخخ آبى. سوسا. توزيع مكانى كادميوم در شاليزارهاى جنوب غربى اصفهان با استفاده از زمسين آمـار و GIS. نشـريه }
$$$$
\text { آب و خاك، علوم و صنايع كشاورزى }
$$

9. زارع ابيانه، ح.، م. بيات وركشى، س. اخوان و م. محمدى. •وسا. تخمين نيترات آب زيرزمينى دشت همـدان- بهـار بـا اسـتفاده از

شبكه عصبى مصنوعى و اثر تفكيك دادهها بر دقت بيشبينى. مجله محيط شناسى

V. صدر، س.، م. افيونى و ن. فتحيانيور. MM M ا. تغييرات مكانى آرسنيك در اراضى با كاربردهاى مختلف در استان اصفهان. نشريه علوم

$$
\text { و فنون كشاورزى و منابع طبيعى، علوم آب و خاى •D(س (I): 9D-VD. }
$$

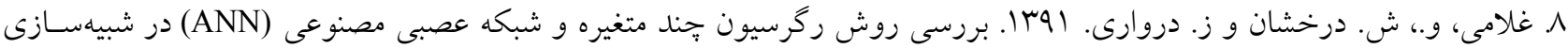

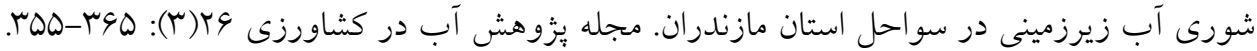

9. فتحى هفشجانى، ا.، ح. ا. بيخى هر:جگانى، ع. داوديان دهكردى و س. ح. طباطبايى. سوسا. مقايسه جند روش درونيـابى مكـانى و

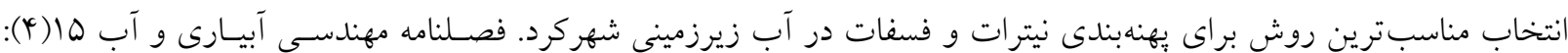

$.01-9 Y$

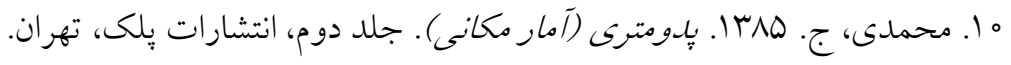

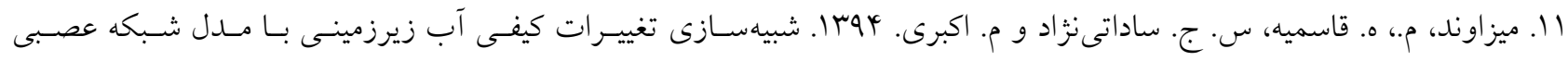

$$
\text { مصنوعى (مطالعه موردى: آبخوان كاشان). مجله منابع طبيعى ايران }
$$

12. Almasri, M. N. and J. J. Kaluarachchi. 2005. Modular neural networks to predict the nitrate distribution in ground water using the on-ground nitrogen loading and recharge data. Environ. Model. Software 20(7): 851-871.

13. ASCE Task Committee on Application of Artificial Neural Networks in Hydrology. 2000. Artificial neural networks in hydrology, I: preliminary concepts. J. Hydrologic Eng. 5(2): 115-123.

14. Chowdhury, M., A. Alouani and F. Hossain. 2010. Comparison of ordinary kriging and artificial neural network for spatial mapping of arsenic contamination of groundwater. Stochastic Environ. Res. and Risk Assess. 24(1): 1-7.

15. Coulibaly, P., F. Anctil and B. Bobée. 2000. Daily reservoir inflow forecasting using artificial neural networks with stopped training approach. J. Hydrology 230: 244-257.

16. Dawson, C. W., R. J. Abrahart, A. Y. Shamseldin and R. L. Wibly. 2006. Flood estimation at ungauged sites using artificial neural networks. J. Hydrology 319: 391-409.

17. Ghaffari Razin, M. R., B. Voosoghi and A. Mohammadzadeh. 2015. Efficiency of artificial neural networks in map of total electron content over Iran. Acta Geodaetica et Geophysica. 1-15.

18. Huiqun, M. and L. Ling. 2008. Water quality assessment using artificial neural network.In 2008 International Conference on Computer Science and Software Engineering 5-13 December, USA.

19. Kheradpisheh, Z., A. Talebi, L. Rafati, M. T. Ghaneian and M. H. Ehrampoush. 2015. Groundwater quality assessment using artificial neural network: A case study of Bahabad plain, Yazd, Iran. Desert 20(1): 65-71.

20. Kouchakzadeh, M. and A. Bahmani. 2006. Assessment of artificial neural networks revenue in reducing required parameters for estimation of reference evapotranspiration. J. Agr. Sci. 11(4): 87-97. 
21. Mirzaei, R. and M. Sakizadeh. 2016. Comparison of interpolation methods for the estimation of groundwater contamination in Andimeshk-Shush plain, southwest of Iran. Environ. Sci. Pollut Res. 23(3): 2758-2769.

22. Nourani, V., M. T. Alami and F. D. Vousoughi. 2016. Self-organizing map clustering technique for ANN-based spatiotemporal modeling of groundwater quality parameters. J. Hydroinformatics 18(2): 288-309.

23. Shapiro, S. S. and M. B. Wilk. 1965. An analysis of variance test for normality (complete samples). Biometrika 52(3-4): 591-611.

24. Zhao, Y. F., X. Zh. Shi, B. Huang, D. Sh. Yu, H. J. Wang, W. X. Sun, I. Oboern and K. Blomback. 2007. Spatial distribution of heavy metals in agricultural soils of an industry-based pre-urban area in Wuxi, China. Pedosphere 17(1): 44-51.

25. Zheng, Z., F. Zhang, X. Chai, Z. Zhu and F. Ma. 2008. Spatial estimation of soil moisture and salinity with neural kriging. In International Conference on Computer and Computing Technologies in Agriculture 1227-1237 October, USA. 


\title{
Performance Evaluation of Geostatistical Methods and Artificial Neural Network in Estimation of Aquifer Quality Parameters (Case Study: Qorveh Dehghan Plain)
}

\author{
M. Isazadeh ${ }^{* 1}$, R. Arabzadeh ${ }^{2}$ and S. Darbandi ${ }^{1}$
}

(Received: Feb. 10-2016; Accepted: May. 23-2016)

\begin{abstract}
Selection of optimum interpolation technique to estimate water quality parameters in unmeasured points plays an important role in managing the quality and quantity of water resources. The aim of this study is to evaluate the accuracy of interpolation methods using GIS and artificial neural network (ANNs) model. To this end, a series of qualitative parameters of samples from water taken from Dehgolan aquifer located in Kurdistan, Iran including CL, EC and PH were evaluated by any of the models. In this study, qualitative data from 56 observation wells with good dispersion in the whole plain was used. The data of 46 observation wells were used for calibration and the data of other 10 wells were used for verification of models. The results showed ANNs, IDW, and Kriging excellence and accuracy over other models in estimation of quality parameters CL, PH and EC. However the ANNs model is more accurate than other models. In case of lack of time and the need for acceptable accuracy and less risk in the estimation of qualitative parameters, the use of ANNs model is superior to other statistical models used.
\end{abstract}

Keywords: Estimation of qualitative parameters, IDW, Kriging, Neural networks.

1. Dept. of Water Eng., Faculty of Agr. Tabriz Univ., Tabriz, Iran.

2. Dept. of Water Eng., Faculty of Agr. Tehran Univ., Tehran, Iran.

*: Corresponding Author, Email: mohammadisazade@gmail.com 